\title{
Pemodelan Metode Deep Sounding TEM untuk Monitoring Injeksi Karbon Dioksida $\left(\mathrm{CO}_{2}\right)$ pada REservoir
}

\author{
Nugroho G.* dan Warsa \\ Teknik Geofisika, Fakultas Teknik Pertambangan dan Perminyakan, Institut Teknologi Bandung, \\ Jalan Ganesa No 10, Bandung, 40132 \\ *Email: gatotnugroho8@gmail.com
}

Submit: 10 April 2017; Revised: 15 Mei 2017; Accepted: 18 Mei 2017

Pemantauan distribusi $\mathrm{CO}_{2}$ merupakan salah satu hal yang sangat penting dalam keberlanjutan CCS. Sampai saat ini pemantauan geofisika yang sering digunakan adalah metode seismik. Penelitian ini dimaksudkan untuk mengetahui kemampuan metode deep TEM untuk melakukan pemantauan pada CCS melalui pemodelan metode deep TEM untuk simulasi pemantauan injeksi CO2. Data TEM sebelum dan sesudah dilakukan injeksi $\mathrm{CO}_{2}$ dibandingkan untuk mengetahui pengaruh keberadaan CO2. Data TEM sebelum injeksi diperoleh dari pengukuran di lapangan pada tahun 2013. Data TEM setelah injeksi diperoleh dari hasil pemodelan ke depan dengan parameter model yang diperoleh dari hasil inversi data TEM lapangan. Pemodelan inversi dilakukan dengan menggunakan metode inversi SVD damped least square. Proses inversi SVD digunakan untuk mengidentifikasi reservoir dan memetakan distribusi $\mathrm{CO} 2$ pada reservoir. Hasil pemodelan inversi satu dimensi diolah menjadi model dua dimensi dengan menggunakan perangkat lunak Rockworks16. Hasil pemodelan inversi data TEM lapangan menunjukkan bahwa reservoir mempunyai resistivitas rendah yaitu $2 \Omega \mathrm{m}$ sampai $4 \Omega \mathrm{m}$. Reservoir ini berada pada kedalaman $900 \mathrm{~m}$ sampai $1200 \mathrm{~m}$ di bawah permukaan. Perbandingan data TEM sebelum injeksi $C O 2$ dan setelah injeksi $\mathrm{CO} 2$ menunjukkan adanya pengaruh $\mathrm{CO} 2$ terhadap kurva data TEM sebelum dan setelah injeksi $C O 2$ secara jelas. Pola kurva data TEM setelah injeksi menenjadi lebih curam pada bagian tengah dari pada kondisi sebelum ada injeksi $C O 2$. Perubahan kurva TEM yang menjadi lebih curam tersebut disebabkan oleh keberadaan $\mathrm{CO} 2$ pada reservoir meningkatkan resistivitas reservoir. Lapisan reservoir setelah injeksi mempunyai resistivitas yang lebih tinggi membuat waktu peluruhan medan elektromagnetik pada lapisan tersebut menjadi lebih cepat, sehingga kurvanya menjadi lebih curam. Hasil pemodelan inversi setelah dilakukan injeksi CO2 mempunyai kesalahan perhitungan yang cukup kecil yaitu kurang dari 5\%. Meskipun mempunyai kesalahan yang kecil hasil yang diperoleh tidak sesuai dengan kondisi yang sebenarnya. Hasil yang tidak sesuai tersebut dikarenakan solusi metode SVD damped least square bukan merupakan solusi yang unik. Selain itu, pendekatan lokal yang digunakan pada metode inversi tersebut membuat nilai minimum yang diperoleh saat proses inversi merupakan nilai minimum lokal. Sehingga hasil yang diperoleh tidak bisa me- nunjukkan pengaruh data secara keseluruhan meskipun dengan nilai kesalahan perhitungan yang kecil. Secara umum hasil yang diperoleh dari proses inversi tidak bisa diterima, akan tetapi dari masing-masing titik data dapat teramati adanya peningkatan resistitas reservoir dari $1 \Omega \mathrm{m}$ sampai 3 $\Omega \mathrm{m}$.

Kata kunci: $T E M, C O 2$, pemantauan, pemodelan kedepan, inversi.

\section{PENDAHULUAN}

Carbon Capture and Storage (CCS) merupakan suatu cara yang efektif untuk mengurangi emisi karbon dioksida. Carbon Capture and Storage (CCS) dilakukan dengan menangkap karbon dioksida $\mathrm{CO}_{2}$ yang ada di lingkungan atau hasil dari industri. Karbon dioksida yang ditangkap lalu dialirkan untuk dimasukkan kedalam reservoir tempat penyimpanan. CCS selain bermanfaat untuk mengurangi konsentrasi karbon dioksida di udara juga bisa digunakan untuk keperluan yang lebih ekonomis seperti Enhance Oil Recovery (EOR).

Untuk memastikan bahwa $\mathrm{CO}_{2}$ yang dimasukkan ke dalam reservoir benar-benar masuk ke reservoir diperlukan pengamatan. Pengamatan $\mathrm{CO}_{2}$ yang dinjeksikan merupakan salah satu bagian yang sangat penting dalam CCS (1). Selain untuk memastikan bahwa $\mathrm{CO}_{2}$ masuk ke reservoir, pengamatan juga diperlukan untuk memastikan bahwa reservoir yang digunakan tidak mengalami kebocoran selama proses injeksi $\mathrm{CO}_{2}$. Kebocoran reservoir akan menimbulkan dampak yang sangat berbahaya bagi lingkungan, sehingga hal tersebut harus dicegah. Salah satu caranya yaitu dengan pengamatan.

Pengamatan geofisika sensitif terhadap perubahan yang terjadi di bawah permukaan akibat proses injeksi $\mathrm{CO}_{2}(2)$. Berbagai metode geofisika sangat efektif sebagai cara untuk melakukan pengamatan pada CCS. Metode geofisika yang telah terbukti efektif untuk melakukan pengamatan CCS adalah passive seismic, deformasi permukaan, log neutron dan time lapse gravity. Sampai saat ini metode seismik merupakan metode geofisika yang paling banyak digunakan untuk pengamatan CCS.

Metode deep sounding TEM merupakan salah satu metode geofisika yang sensitif terhadap resistivitas batuan 
di bawah permukaan. Resistivitas batuan yang berbeda akan menimbulkan respon medan elektromagnetik atau dalam hal ini adalah medan magnet Bz. Batuan yang mempunyai resistivitas lebih tinggi mengakibatkan peluruhan medan $\mathrm{Bz}$ menjadi lebih cepat. Sebaliknya resistivitas yang lebih kecil membuat peluruhan medan $\mathrm{Bz}$ menjadi lebih lambat.

Ada korelasi yang kuat antara perubahan saturasi $\mathrm{CO}_{2}$ dengan perbuhan saturasi air pada reservoir. Perubahan saturasi air tersebut menyebabkan adanya perubahan resistivitas batuan di reservoir. Adanya perubahan resistivitas batuan di reservoir menyebabkan medan elektromagnetik atau medan $\mathrm{Bz}$ yang terukur di permukaan juga berubah. Hal ini membuat metode deep sounding TEM bisa menjadi alat untuk pengamatan pergerakan $\mathrm{CO}_{2}$ di reservoir. Simulasi pengamatan $\mathrm{CO}_{2}$ dengan metode deep sounding TEM perlu dilakukan untuk memastikan kemampuan dari metode ini sebelum diterapkan pada data lapangan. Oleh karena itu penelitian ini mencoba untuk mengetahui kemampuan metode Deep Sounding ransient Electromagnetic dalam melakukan pengamatan injeksi $\mathrm{CO}_{2}$ pada reservoir CCS.

\section{PEMODELAN KE DEPAN}

Ward dan Hofmann (1988) (3) memformulasikan persamaan matematika intensitas medan magnetik vertikal yang dihasilkan oleh pengukuran satu dimensi metode TEM dengan konfigurasi grounded wire. Intensitas medan magnetik vertikal yang dihasilkan oleh arus injeksi dirumuskan oleh:

$$
H_{z}=\frac{1}{4 \pi} \int_{-L}^{L} \frac{y}{r} \int_{0}^{\infty}\left(1+r_{T E}\right) e^{u_{0} z} \frac{\lambda^{2}}{u_{0}} \jmath(\lambda r) d \lambda d x^{\prime}
$$

Dimana $I$ adalah arus yang diinjeksikan, $L$ adalah setengah panjang transmitter, $d s$ panjang transmitter, $R_{o f f s e t}, r_{T E}$ adalah koefisien refleksi antar lapisan, $\lambda$ variabel integrasi transformasi Hankel, $J_{1}$ fungsi Bessel orde satu. $r_{T E}$ dihitung dengan menggunakan persamaan:

$$
\begin{gathered}
r_{n}^{T E}=\frac{r_{n+1}^{T E}+\psi_{n+1}^{T E} r_{n+1}^{T E}+\psi_{n+1}^{T E}+1}{e^{-2 u_{0} h_{n}}} \\
\psi_{n}^{T E}=\frac{\frac{u_{n}}{\hat{y}_{n}}-\frac{u_{n+1}}{\hat{y}_{n+1}}}{\frac{u_{n}}{\hat{y}_{n}}+\frac{u_{n+1}}{\hat{y}_{n+1}}}
\end{gathered}
$$

Dimana:

$u_{n}=\left(k_{x}^{2}+k_{y}^{2}-k_{n}^{2}\right)^{1 / 2}$,

$\hat{y}=\sigma_{n}+i \varpi \varepsilon_{n}$

$k_{x}^{2}=\varpi^{2} \varepsilon_{n} \mu_{n}-i \varpi \varepsilon_{n} \sigma_{n}$,

$h_{n}$ adalah ketebalan lapisan ke-n

$\sigma_{n}$ adalah konduktifitas lapisan ke-n

$\varepsilon_{n}$ permitivitas dielektrik lapisan ke-n

$\mu_{n}$ permeabilitas magnetik lapisan ke-n

perhitungan transformasi Hankel menggunakan algoritma Fast Hankel Transform dengan 101 point filter digital yang dibuat oleh Anderson (1979). Untuk mengubah dari domain frekuensi menjadi domain waktu digunakan digital filter cosin.

\section{INVERSI SVD DAMPED LEAST SQUARE}

Penerapan metode SVD membuat inversi matriks menjadi lebih stabil (4). Solusi damped least square dinyatakan oleh persamaan:

$$
\Delta p=\left(A^{T} A+\varepsilon^{2} I\right)^{-1} A^{T} \Delta d
$$

Dimana $\Delta p$ adalah matriks koreksi parameter, $A$ matriks Jacobian, $\varepsilon$ faktor peredam, $I$ matriks identitas, dan $\Delta d$ adalah matriks perubahan data.

Solusi matriks Jacobian A dengan dengan menggunakan metode SVD dinyatakan oleh persamaan:

$$
A=U S V^{T}
$$

Dimana $\mathrm{U}$ adalah matriks (nxp), S adalah matriks diagonal (pxp) dari nilai singular $\mathrm{A}$, dan $\mathrm{V}$ adalah matriks (pxp) dengan $n$ merupakan jumlah data dan $\mathrm{p}$ adalah jumlah parameter.

Dengan substitusi Persamaan (5) ke Persamaan (4) diperoleh solusi inversi SVD damped least square yang dinyatakan oleh persamaan:

$$
\Delta p=\left(V S^{2} V^{T}+\varepsilon^{2} I\right)^{-1} V S U^{T} \Delta d
$$

Kesalahan perhitungan inversi dilakukan dengan menggunakan perhitungan root-meansquare (rms) dalam persen.

$$
r m s(\%)=\sqrt{\frac{\sum_{j=1}^{N}\left(\frac{d_{j}^{\text {obs }}-d_{j}^{c a l}}{d_{j}^{\text {obs }}}\right)^{2}}{N}} \times 100
$$

Dimana $d^{\text {obs }}$ adalah data observasi, $d^{c a l}$ adalah data perhitungan, dan $\mathrm{N}$ adalah jumlah data yang dilakukan perhitungan.

\section{HASIL DAN DISKUSI}

Pemodelan ke depan dengan menggunakan model resistivitas homogen half space dan model 2 lapisan dilakukan untuk mengetahui pola kurva medan Bz metode TEM sounding. Hasil pemodelan ke depan menunjukkan bahwa homogen resistif $(100 \Omega \mathrm{m})$ memiliki pola kurva TEM sounding yang lebih curam dari pada model konduktif (10 $\Omega \mathrm{m})$ yang mempunyai kurva sounding lebih landai (Gambar 1).

Adanya perbedaan pola kurva lapisan resistif yang lebih curam dari lapisan konduktif ini disebabkan karena medium yang konduktif berperan sebagai "Trap" bagi medan elektromagnetik yang melewatinya. Di dalam lapisan yang konduktif medan elektromagnetik akan mengalami sirkulasi. Akibat dari adanya sirkulasi tersebut membuat laju difusi medan elektromagnetik pada lapisan konduktif menjadi lebih lambat dari media yang resistif.

Dua parameter model yang mempunyai resistivitas hampir sama dimodelkan untuk mengetahui bagaimana respon kurva TEM sounding yang terbentuk karena adanya perubahan resistivitas yang cukup kecil. Model dibuat dengan perbedaan resistivitas sebesar $5 \Omega \mathrm{m}$ pada lapisan setebal $800 \mathrm{~m}$ yang lebih konduktif dari lingkungannya. Kurva TEM sounding yang dihasilkan dari pemodelan ke depan tersebut menunjukkan adanya sedikit perbedaan pada kurva TEM sounding. Perbedaan terjadi di bagian tengah hingga akhir 


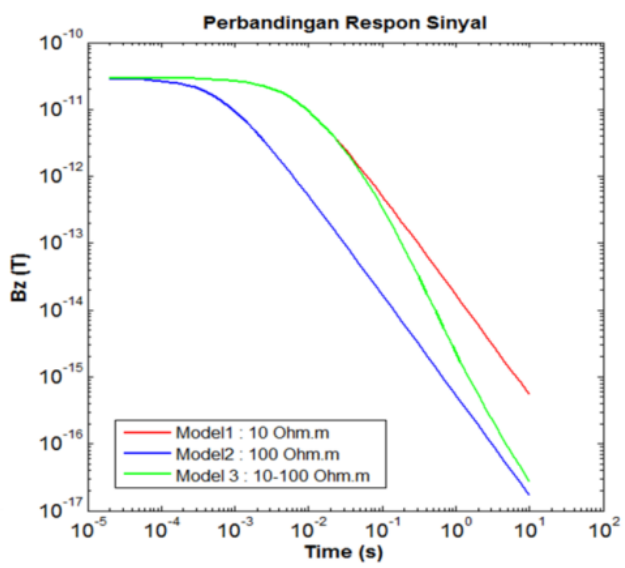

Gambar 1. Pemodelan ke depan model homogen half space.

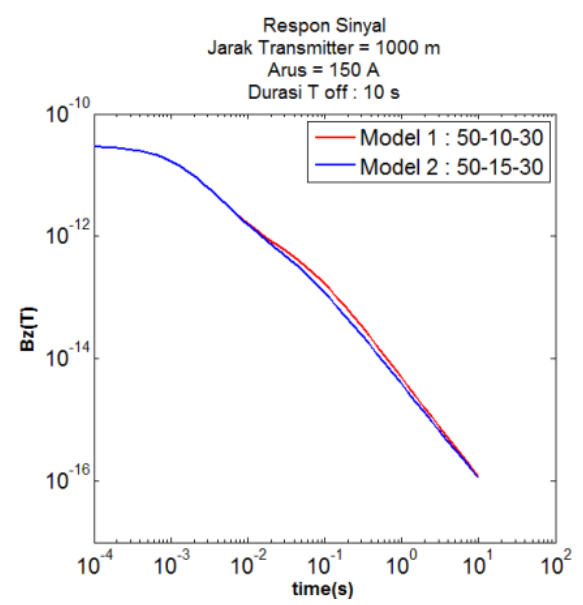

Gambar 2. Sensitifitas pemodelan ke depan.

waktu pengukuran. Model dengan resistivitas lebih resistif $(15 \Omega \mathrm{m})$ pada lapisan kedua (warna biru) mempunyai pola kurva TEM sounding yang lebih curam (Gambar 2). Model dengan resistivitas lebih konduktif $(10 \Omega \mathrm{m})$ pada lapisan kedua (warna merah) mempunyai kurva yang lebih landai pada bagian tengah hingga akhir waktu pengukuran.

Hasil tersebut sesuai dengan karakter kurva TEM sounding yang menunjukkan bahwa lapisan yang lebih resistif mempunyai pola kurva yang lebih curam. Meskipun dapat menunjukkan adanya perubahan pada kurva TEM sounding akan tetapi perubahan pola kurva yang dihasilkan cukup kecil dengan ketebalan lapisan yang cukup besar tersebut $(800 \mathrm{~m})$.

Model sintetik 3 lapis (Gambar 3 atas) dan model 3 lapis yang telah mengalami perubahan resistivitas pada lapisan kedua (Gambar 3 bawah) dibuat untuk menguji metode sensitifitas metode inversi terhadap perubahan resistivitas yang cukup kecil pada lapisan yang tipis.

Hasil inversi dapat menunjukkan adanya perubahan resistivitas pada lapisan yang cukup tipis (Gambar 4b) dari kondisi awalnya (Gambar 4a). Resistivitas pada kedalaman $900 \mathrm{~m}$ sampai $1300 \mathrm{~m}$ berubah dari yang semula 5 $\Omega \mathrm{m}$ menjadi $15 \Omega \mathrm{m}$. Hasil inversi ini juga cukup representatif terhadap model sebenarnya dengan kesalahan perhi-

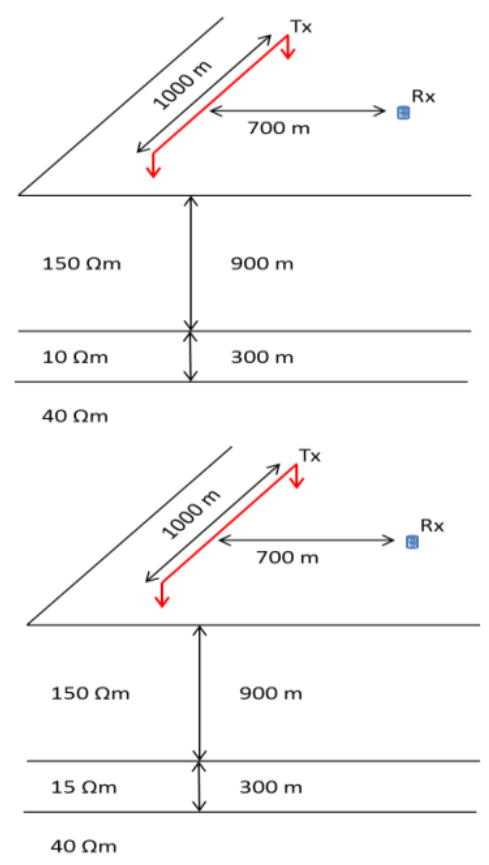

Gambar 3. Parameter model uji sensistifitas. Model sebelum terjadi perubahan resistivitas (atas) model setelah terjadi perubahan resistivitas pada lapisan tipis (bawah).

tungan yang cukup kecil yaitu i $1 \%$. Hal tersebut ditunjukkan dengan hasil inversi (kurva hitam) yang fit terhadap model sebenarnya (kurva hijau) pada Gambar 4. Dengan demikian metode inversi yang digunakan kemungkinan juga bisa melakukan identifikasi perubahan resistivitas di lapisan yang tipis pada data lapangan.

Hasil inversi medan Bz titik E000N100 menunjukkan adanya lapisan dengan resistivitas yang rendah yaitu $2 \Omega \mathrm{m}$ sampai $4 \Omega \mathrm{m}$ pada kedalaman $900 \mathrm{~m}$ hingga $1200 \mathrm{~m}$ di bawah permukaan (daerah di antara garis merah putusputus) pada Gambar 5b. Lapisan dengan resistivitas rendah tersebut berada di antara lapisan dengan resistivitas yang sedang (9 $\Omega \mathrm{m}$ sampai $35 \Omega \mathrm{m}$ ) yang masing-masing berada pada kedalaman $700 \mathrm{~m}$ sampai $900 \mathrm{~m}$ dan $1200 \mathrm{~m}$ sampai $1940 \mathrm{~m}$. Resistivitas yang sedang juga terdapat di dekat permukaan sampai kedalaman $100 \mathrm{~m}$. Resistivitas yang tinggi (¿200 $\Omega \mathrm{m})$ terdapat pada kedalaman $100 \mathrm{~m}$ sampai $400 \mathrm{~m}$.

Lapisan dengan resistivitas rendah (2 $\Omega \mathrm{m}$ sampai $4 \Omega \mathrm{m})$ diinterpretasikan sebagai lapisan reservoir yang merupakan batupasir lempungan dari Formasi Ngrayong (Gambar 5). Nilai resistivitas yang rendah disebabkan keberadaan mineral lempung pada lapisan batupasir. Keberadaan air formasi yang saline pada reservoir tersebut membuat lapisan tersebut mempunyai nilai resistivitas yang semakin kecil.

Lapisan dengan resistivitas sedang (9 $\Omega \mathrm{m}$ sampai 35 $\Omega \mathrm{m})$ yang berada di atas dan di bawah lapisan reservoir diinterpretasikan sebagai lapisan batulempung (Gambar 6). Lapisan batulempung di atas lapisan reservoir merupakan bagian dari Formasi Wonocolo. Lapisan batulempung tersebut berfungsi sebagai penutup pada sistem petroleum daerah tersebut. Batulempung dapat berperan sebagai penutup karena mempunyai permeabilitas yang sangat kecil sehingga fluida sulit mengalir di dalamnya. Lapisan 

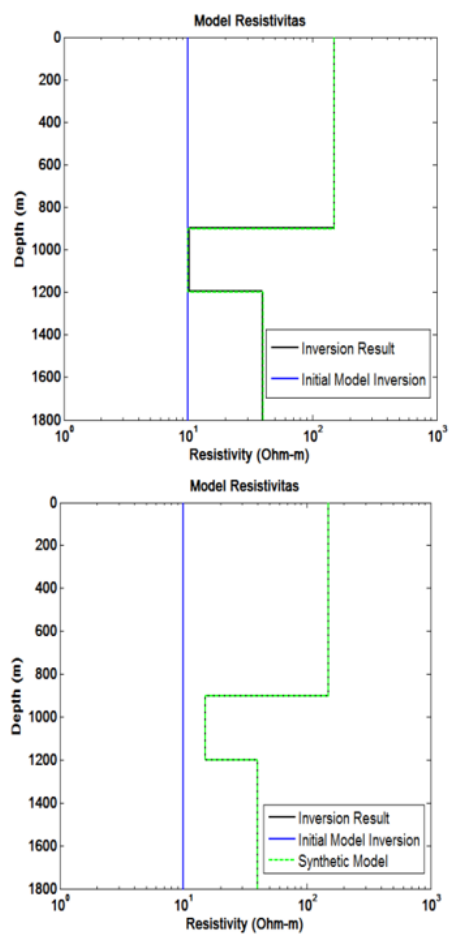

Gambar 4. Pemodelan inversi kondisi awal sebelum resistivitas berubah (awal). pemodelan inversi setelah terjadi perubahan resistivitas (akhir).

(a)

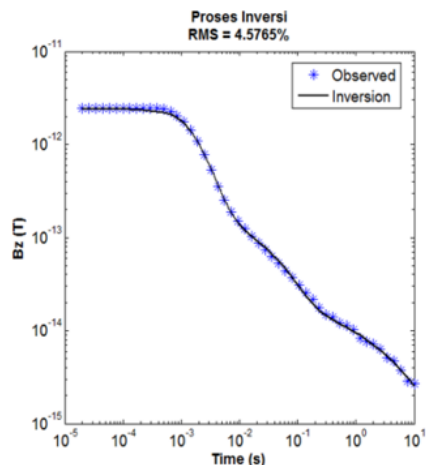

(b)

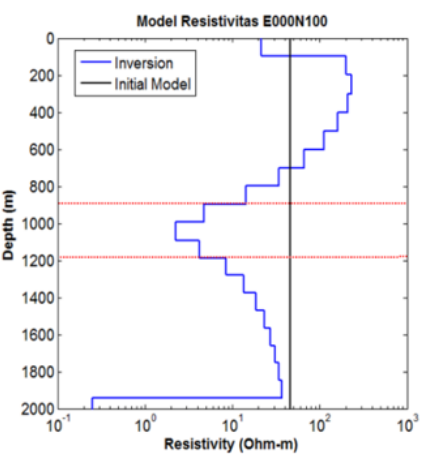

Gambar 5. Identifikasi reservoir titik E000N100. (a) misfit data TEM (b) model resistivitas hasil inversi.

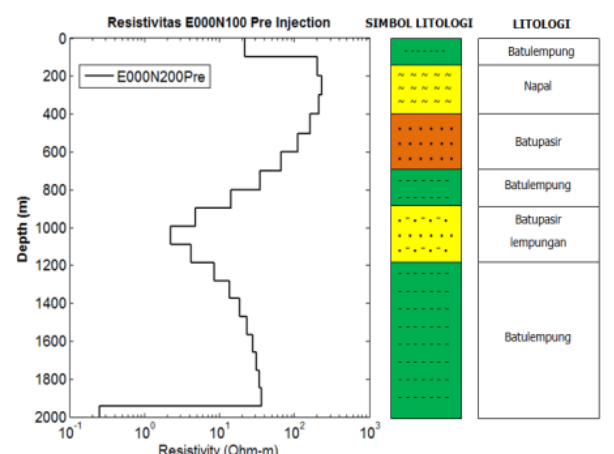

Gambar 6. Interpretasi hasil inversi titik E000N100.

batulempung yang berada di bawah lapisan reservoir merupakan bagian dari Formasi Tawun.

Lapiasan dengan resistivitas sedang di dekat permukaan diinterpretasikan sebagai lapisan batulempung. Lapisan yang mempunyai resistivitas tinggi $(i 200 \Omega \mathrm{m})$ diinterpretasikan sebagai lapisan Napal yang merupakan bagian dari Formasi Mundu. Di bawah lapisan Napal terdapat lapisan dengan resistivitas $65 \Omega \mathrm{m}$ sampai $190 \Omega \mathrm{m}$ pada kedalaman $400 \mathrm{~m}$ sampai $700 \mathrm{~m}$. Lapisan tersebut merupakan lapisan Batupasir yang merupakan bagian dari Formasi Ledok.

Pemodelan ke depan medan magnet Bz dilakukan dengan memberikan perubahan sebesar $7 \Omega \mathrm{m}$ pada lapisan setebal $5 \mathrm{~m}$ yang dianggap sebagai bagian dari lapisan reservoir. Terdapat perubahan yang cukup kecil antara hasil pemodelan ke depan setelah dilakukan injeksi $\mathrm{CO}_{2}$ (garis tegas merah) dengan data lapangan (garis tegas biru) pada Gambar 7. Perubahan tersebut terjadi pada saat tengah waktu pengukuran. Selain terjadi di tengah waktu pengukuran, perubahan pola kurva medan magnet $\mathrm{Bz}$ juga terjadi di akhir waktu pengukuran.

Perubahan yang cukup kecil pada waktu tengah pengukuran tersebut dikarenakan konsentrasi $\mathrm{CO}_{2}$ masih berada pada lapisan yang tipis. Sementara lapisan lain disekitarnya mempunyai ketebalan yang cukup besar dengan beda resistivitas yang cukup besar juga. Oleh karena itu, pengaruh perubahan resistivitas pada lapisan yang tipis terhadap kurva pengukuran medan magnet $\mathrm{Bz}$ belum bisa terlihat dengan jelas. Perubahan pola kurva medan magnet di akhir waktu pengukuran kemungkinan disebabkan oleh data pengukuran lapangan yang masih belum bersih dari noise secara sempurna. Hal tersebut terlihat dari kurvanya yang kurang smooth.

Setelah hasil pemodelan ke depan menunjukkan adanya perubahan pada kurva medan $\mathrm{Bz}$ sebelum dan seudah injeksi maka dilakukan pemodelan inversi data TEM setelah injeksi. Pemodelan inversi dilakukan dengan memberikan parameter model bumi berlapis. Parameter model yang digunakan sesuai degan kondisi sebelum dilakukan injeksi $\mathrm{CO}_{2}$. Proses inversi dilakukan dengan menggunakan dua cara yang berbeda. Cara pertama dilakukan dengan menghitung semua parameter model yang dimasukkan. Cara kedua perhitungan inveri hanya dilakukan pada lapisan yang dianggap sebagai lapisan reservoir.

Hasil inversi data TEM seletah injeksi $\mathrm{CO}_{2}$ titik E000N100 ditunjukkan oleh Gambar 8. Hasil inversi yang diperoleh dengan menggunakan cara yang pertama maupun 


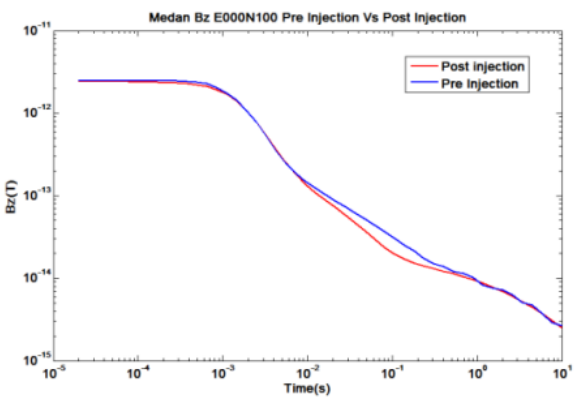

Gambar 7. Perbandingan data TEM sebelum dan sesudah injeksi $C O 2$ titik E000N100.

yang kedua mempunyai kesalahan perhitungan yang kecil yaitu kurang dari $5 \%$. Kesalahan perhitungan yang kecil ini mengindikasikan bahwa hasil yang diperoleh cukup merepresentasikan data pengamatan.

Meskipun hasil pemodelan inversi (garis hitam) titik E000N100 setelah dilakukan injeksi $\mathrm{CO}_{2}$ mempunyai kesalahan perhitungan yang kecil, model yang diperoleh masih belum bisa menunjukkan model yang sebenarnya (garis merah). Hasil inversi dengan menggunakan cara pertihungan semua parameter model sangat jauh dari model yang sebenarnya (Gambar 8a). Hampir semua lapisan mengalami perubahan resistivitas dari kondisi awal sebelum dilakukan injeksi (garis biru). Hal ini dikarenakan ketidakunikan dari solusi inversi non linier menggunakan pendekatan linier dengan metode SVD damped least square. Sehingga hasil inversi yang diperoleh tidak sesuai dengan kondisi sebenarnya meskipun kesahalan perhitungannya cukup kecil. Untuk mengatasi permasalahan ini kemungkinan bisa diselesaikan dengan menggunakan proses inversi non linier.

Proses inversi yang dilakukan dengan membuat resistivitas lapisan selain reservoir tidak berubah dapat menunjukkan bahwa hasil inversi (garis hitam) lapisan selain reservoir tidak mengalami perubahan resistivitas. Perubahan resistivitas dari kondisi awal sebelum ada injeksi $\mathrm{CO}_{2}$ (garis biru) terlihat hanya pada lapisan reservoir (Gambar $8 \mathrm{~b}$ ). Meskipun terlihat adanya perubahan resistivitas reservoir, perubahan yang terjadi hanya kecil. Hasil inversi pada lapisan reservoir bagian atas hampir tidak menunjukkan adanya perubahan. Lapisan bagian tengah mengalami penurunan resistivitas yang cukup kecil kurang dari $1 \Omega \mathrm{m}$. Lapisan bagian bawah mengalami peningkatan resistivitas sekitar $2 \Omega \mathrm{m}$. Hasil tersebut masih tidak sesuai dengan model sintetik (garis merah) yang merupakan model sebernarnya yang seharusnya dihasilkan oleh proses inversi.

Ketidakmampuan model inversi mencapai model sintetik yang seharusnya meskipun hasil perhitungannya mempunyai kesalahan yang kecil kemungkinan disebabkan oleh ketidakunikan metode SVD damped least square serta pendekatan yang dilakukan oleh metode inversi SVD damped least square. Untuk kasus ini perhitungan metode inversi yang digunakan SVD tidak menggunakan pendekatan glogal. Akibatnya nilai minimum yang diperoleh merupakan nilai minimum lokal bukan global. Pada saat nilai minimum lokal tersebut tercapai, nilai tersebut bukan merupakan nilai minimum global yang merupakan solusi dari inversi data secara keseluruhan. Akibatnya model yang didap-
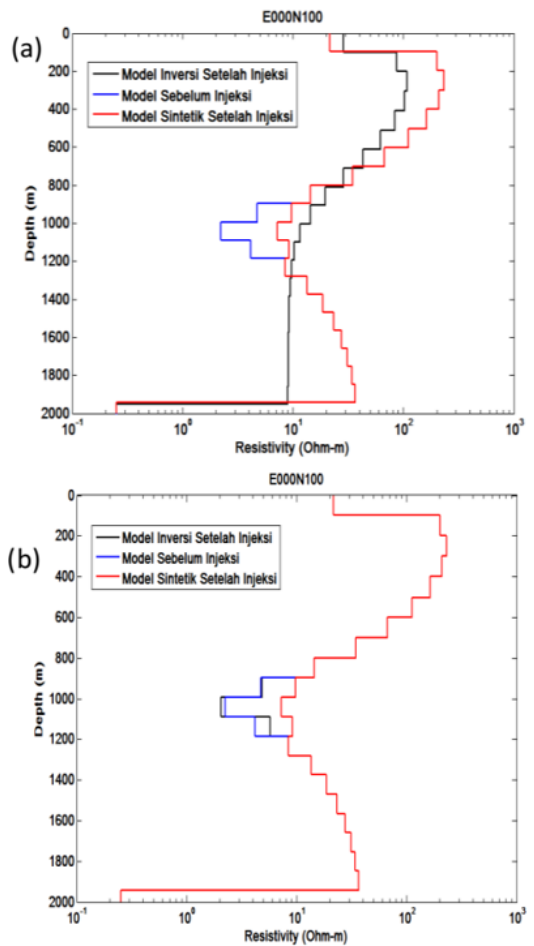

Gambar 8. Proses inversi titik E000N100 setelah dilakukan injeksi $\mathrm{CO}_{2}$. (a) proses inversi pada semua lapisan (b) proses inversi pada lapisan reservoir saja.

atkan kurang sesuai dengan model yang sebenarnya. Model resistivitas hasil inversi yang sesuai dengan model sebenarnya kemungkinan akan diperoleh saat pendekatan perhitungan inversi yang dilakukan adalah menggunakan pendekatan global seluruh data.

Proses pemodelan ke depan dilakukan untuk mendapatkan data TEM sintetik setelah injeksi $\mathrm{CO}_{2}$. Parameter model yang digunakan adalah hasil inversi keempat titik yang diiversi dengan melakukan perubahan resistivitas sebesar $5 \Omega \mathrm{m}$ pada lapisan reservoir. Perubahan tersebut merupakan dampak dari injeksi $\mathrm{CO}_{2}$ setelah 40 hari dengan laju injeksi 6 ton/hari. Jumlah total $\mathrm{CO}_{2}$ yang diinjeksikan adalah 240 ton selama kurun waktu tersebut. Data TEM sintetik hasil pemodelan dianggap sebagai data pemangatan untuk dilakukan pemodelkan inversi.

Dalam melakukan pemodelan ke depan data TEM setalah injeksi dilakukan beberapa asumsi sebagai berikut:

(i) sebelum dilakukan injeksi $\mathrm{CO}_{2}$ reservoir tersaturasi air $100 \%$.

(ii) $\mathrm{CO}_{2}$ yang diinjeksikan $100 \%$ masuk kedalam poripori reservoir.

(iii) $\mathrm{CO}_{2}$ di dalam reservoir terdistribusi merata pada lapisan reservoir untuk setiap titik pengukuran.

(iv) $\mathrm{CO}_{2}$ yang diinjeksikan berfasa superctritical.

Pemodelan inversi dilakukan dengan menggunakan model awal sesuai dengan kondisi sebelum dilakukan injeksi $\mathrm{CO}_{2}$. Hasil yang diperoleh dari pemodelan tersebut secara umum semua titik pengukuran tidak mengalami perubahan resistivitas yang signifikan. Meskipun proses perhitungannya mempunyai kesalahan yang cukup kecil hasil yang diperoleh dianggap tidak sesuai dengan kondisi yang sebenarnya. Pe- 


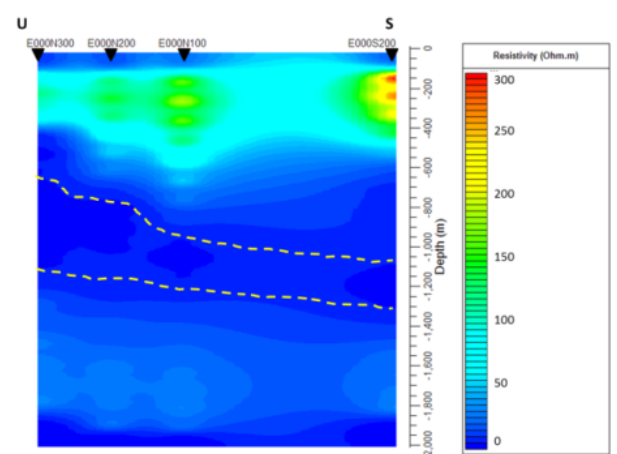

Gambar 9. Model resistivitas 2D sebelum dilakukan injeksi $\mathrm{CO}_{2}$.

rubuahan resistivitas yang terjadi kurang dari $3 \Omega \mathrm{m}$ baik yang meningkat maupun yang munurun nilai resistivitasnya. Oleh karena itu, hasil yang diperoleh dianggap kurang sesuai dengan kondisi yang seharusnya.

Pendekatan pemodelan dua dimensi dari data satu dimensi dilakukan dengan menggunakan perangkat lunak RockWorks16. Warna biru tua menunjukkan resistivitas yang rendah dan warna merah menunjukkan resistivitas yang tinggi. Lapisan reservoir yang mempunyai resistivitas rendah ditunjukkan oleh warna biru tua yaitu daerah di antara garis putus-putus kuning (Gambar 9). Resistivitas yang rendah ini dianggap sebagai lapisan batupasir lempungan yang merupakan batuaan reservoir. Segitiga hitam pada Gambar 9 menunjukkan lokasi data satu dimensi yang dimodelkan menjadi dua dimensi. Pada sisi kanan dan kiri gambar terlihat adanya resistivitas yang kontras dengan daerah di sekitarnya. Hal tersebut disebabkan oleh adanya efek tepi dari proses pemodelan dua dimensi dari data satu dimensi yang dilakukan.

Nilai resisitivitas rendah yang ditandai dengan warna biru tidak terlihat di antara titik data E000N100 dan E000S200. Hasil ini disebabkan oleh kurangnya data satu dimensi yang dimodelkan. Proses interpolasi yang terlalu jauh secara horizontal menyebabkan pada interval tersebut nilai resistivitasnya lebih dominan disebabkan oleh interpolasi secara vertikal. Sementara nilai resistivitas di atas lapisan reservoir pada satu titik data sounding lebih tinggi daripada resistivitas reservoir pada titik data sounding satu dengan yang lainnya pada kedalaman yang sama. Akibatnya interpolasi pada interval tersebut menjadi lebih besar daripada daerah sekelilingnya secara horizontal. Pada interval ini hasil yang diperoleh kurang bisa diterima.

Pengaruh dari adanya injeksi $\mathrm{CO}_{2}$ ke dalam reservoir tidak bisa ditunjukkan secara jelas dari penampang resistivitas dua dimensi (Gambar 10). Gambar 10 menunjukkan resistivitas setelah dilakukan injeksi $\mathrm{CO}_{2}$ yang secara umum sama dengan resistivitas sebelum dilakukan injeksi $\mathrm{CO}_{2}$ (Gambar 9). Perubahan resistivitas kecil kurang dari $3 \Omega \mathrm{m}$ yang terjadi tidak bisa ditunjukkan oleh penampang dua dimensi tersebut. Hal tersebut dikeranakan interval pengeplotan warna dilakukan dengan menggunakan rentang 3 $\Omega \mathrm{m}$. Sehingga perubahan dibawah $3 \Omega \mathrm{m}$ kemungkinan besar tidak bisa teresolusi dengan baik. Ditambah jarak data yang diinterploasi juga terlalu jauh.

Meskipun perubahan resistivitas tidak bisa terlihat dari

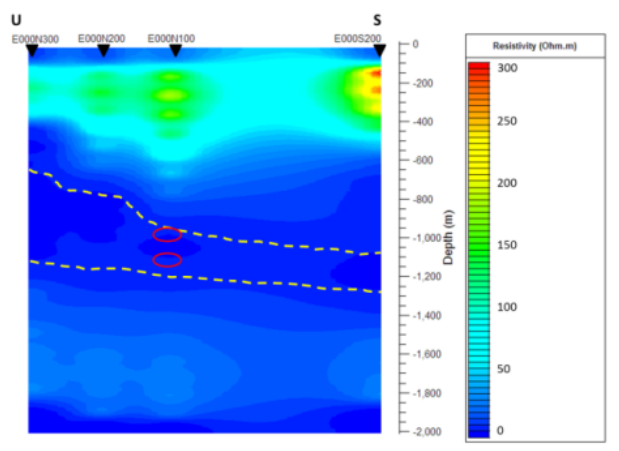

Gambar 10. Model resistivitas 2D setelah injeksi $\mathrm{CO}_{2}$ sebanyak 240 ton setelah 40 hari injeksi.

penampang resistivitas 2D yang ditunjukkan oleh Gambar 9 dan Gambar 10, perubahan resistivitas dapat terlihat dari hasil inversi untuk semua titik pengukuran. Proses inversi yang dilakukan dengan teknik konstrain pada semua lapisan selain reservoir menunjukkan adanya peningkatan resistivitas yang cukup kecil yaitu kurang dari $3 \Omega \mathrm{m}$. Dengan demikian metode deep sounding TEM ini dianggap bisa mengidentifikasi perubahan resistvitias pada reservoir dengan catatan metode inversi yang digunakan sensitif terhadap perubahan resistivitas yang kecil seperti metode inversi Monte Carlo. Teknik inversi yang digunakan sebaiknya juga menggunakan teknik inversi 3D dengan konstrain untuk semua lapisan selain lapisan reservoir untuk mengetahui pergerakan $\mathrm{CO}_{2}$ pada reservoir.

\section{KESIMPULAN}

Dari analisis hasil penelitian, dapat disimpulkan bahwa hasil inversi data TEM menunjukkan bahwa lapisan yang dianggap sebagai reservoir mempunyai litologi berupa batupasir lempungan dengan resistivitas rendah $2 \Omega \mathrm{m}$ sampai $4 \Omega \mathrm{m}$ pada kedalaman $900 \mathrm{~m}$ hingga $1200 \mathrm{~m}$. Metode inversi SVD damped least square dapat menunjukkan adanya perubahan resistivitas yang kecil pada reservoir akibat injeksi $\mathrm{CO}_{2}$, akan tetapi hasil tersebut tidak sesuai dengan kondisi yang sebenarnya.Injeksi $\mathrm{CO}_{2}$ sebesar 240 ton selama 40 hari yang seharusnya bisa menyebabkan peningkatan resistivitas sebesar $5 \Omega \mathrm{m}$ tidak teridentifikasi dengan jelas menggunakan metode inversi SVD damped least square.

\section{REFERENCES}

Zhdanov, M.S., Endo, M., Black, N., Spangler, L., Fairweather, S., Hibbs, A., Eiskamp, G.A., and Will, R. (2013). Electromagnetic pengamatan of $\mathrm{CO}_{2}$ sequestration in deep reservoirs. First Break, 31.

Strickland, C.E., Vermeula, V.R., Bonneville, A., Sullivan, E.C., Johnson, T.C., Spane, F.A., and Gilmore, T.J. (2014). Geophysical pengamatan methods evaluation for the FutureGen 2.0 project. Energy Procedia, 63, 4394-4403.

Ward, S.H., and Hohmann, G.W. (1988) Electromagnetic Theory for Geophysical Applications in Electromagnetic Methods. in Applied Geophysics Vol. I. 131-311, ed. Nabighian M.N., SEG, Tulsa. 
Grandis, H. (2009) Pengantar Pemodelan Inversi Geofisika. Himpunan Ahli Geofisika Indonesia (HAGI). 